\title{
ザンビアにおける公営住宅払い下げ政策とその影響 THE EFFECT AND IMPACT OF THE SALE OF PUBLIC HOUSING IN ZAMBIA
}

\author{
阪東 美智子*, 塩崎 賢 明** \\ Michiko BANDO and Yoshimitsu SHIOZAKI
}

\begin{abstract}
In Zambia, the new government has promoted the home ownership scheme which involved the selling of public housing to sitting tenants. The Progromme faces the problems such as:

(1) Credit finance is far beyond the reach of the low-income household.

(2) Some of the legal registered tenants have not been occupying the houses.

(3) Most of the sold housing are very old. The government trasfers the responsiblity of repairing the houses to the sitting tenants.

The sale of public housing is reducing the amount of affordable housing in the low income housing market. It causes a increase in the number of squatter housing.
\end{abstract}

\author{
Keywords : Zambia, Housing Policy, Public Housing, Privatisation, Structural Adjustment, \\ Squatter \\ ザンビア、住宅政策、公営住宅、民営化、構造調整、スクウォッター
}

\section{1. 研究の背景・目的}

近年、欧米先進国のほとんどで、住宅政策は、「新規の公共住宅 への支援を削減し、既存の公共住宅入居者について家貨を市場水準 近くに引き上げ、公共部門よりも民間部門により大きく依存させる 1)」方向に転換してきた。こうした動きは、住宅市場が比較的整備 されている先進国だけにみられるものではない。発展途上国に扔い ても、世界銀行とIMFが主導する「構造調整計画」の一環として、 民間活力の導入や価格の自由化などが実施されている。しかし、こ の計画は社会的サービスを低下させるため、貧困層に大きな犠牲を 強いる結果となっているる゙ 。

ザンビアでは、構造調整計画のもと1996年から公営住宅の払い下 壮が本格的に進めら扎ているが、早くもその弊害が社会問題となっ ている。本研究では、ザンビアに扔ける公営住宅払い下げシステム と現状、住宅市場への影響、公営住宅居住者の動向を調查し、ザン ビアの公営住宅払い下げ政策が抱える問題点一特に低所得層への影 響一を明らかにする。

\section{2. 既存研究と本研究の位置づけ}

公営住宅の払い下げ政策に関する既存研究としては、鈴木 ${ }^{4}$ がイ ギリスにおける展開を紹介している。福島・大西 ${ }^{5}$ は、発展途上国
の1つであるマレーシアの民活型居住政策を研究しているが、これは 土地の民営化を主題としたものである。瀬戸口 ${ }^{6)}$ は、民主化に伴う ロシアの公営住宅事業の転換を、受益者負担の概念の導入という観 点から紹介している。しかし、発展途上国の公営住宅の払い下げに 関する研究は、これまでのところない。

\section{3. 研究方法}

ザンビアの住宅制度や、公営住宅払い下げ政策の導入経緯に関し ては、関連論文や文献、統計資料などをもとにしている。公営住宅 の払い下げの現状や問題点に関しては、1996年と1997年にザンビア の2都市で行われたザンビア国立コッパーベルト大学の学生の調査研

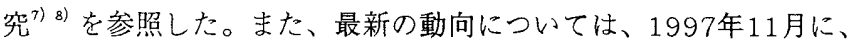
ザンビアの関係諸機関（大学・政府・市役所）において行った担当 者への直接インタビューや収集した関連資料に基づいている。

\section{4. 研究の対象地域一ザンビア一}

ザンビアは、アフリカ大陸の内陸部に位置し、面積は約75.3万 $\mathrm{km}^{2} 、 人 口 は 894 万 人 （ 1993$ 年）である。1920年代末からの)銅鉱山開 発によって栄えたイギリス政府の旧植民地であり、1964年10月24日 に独立した。現在は、9つの州からなり、57の行政管区がある。サ八

\footnotetext{
* 神戸大学大学院自然科学研究科 大学院生 $\cdot$ 工修

Graduate Student, Institute of Natural Science, Graduate School of Kobe University, M. Eng.

** 神戸大学工学部建設学科 助教授・工博

Assoc. Prof., Dept. of Construction, Faculty of Engineering, Kobe University, Ph. D. Eng.
} 
ラ以南アフリカでは最も都市化の進んだ国の一つであり、10大都市 人口の対棇人口比は $32.8 \%$ である゙。国民総生産は 3152 百万ドル

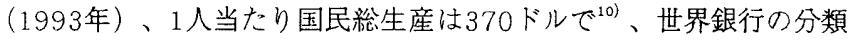
では、低所得国グルーブに数えられている。

\section{5. 公営住宅払い下げ政策の背景}

ザンビアの政治は、植民地時代（～1964年）、第一・二共和制時 代（1964～1991年）、民主化の時代（1991年～現在）の3つに区分 することができる。特に、1991年の新政権誕生は、「社会主義」か ら「民主主義」への大きな転機であり、住宅政策においてもこの時 期から民活の導入や民営化が奖励されている。

公営住宅払い下げ政策の導入の背景として、住宅政策の推移を、 上記区分に従って概観する（表1） ${ }^{11) 16)(11) 。 ~}$

（1）植民地時代（～1964年）

ザンビアは、そもそも、英国南アフリカ会社がイギリス政府に代 わって行政権を行使していた国である。1924年に行政権はイギリス 政府に返還されるが、それまでは、この鉱山企業が統治していた。 このため、各種の政策も鉱山企業を中心としたものであった。1917 年に、初めての社会福祉法である「鉱山健康保健規則（Mines Health and Sanitation Regulations)」が制定され、この法律によっ て、大規模鈗山企業は雇用人に適切な住宅を供給することが義務づ けられた。以後、植民地時代の住宅政策は、アフリカ人の農村・都 市間の労働移動の規制および都市人口の調整を目的として、雇用政 策と結びついたものとして展開していった。1929年の「原住民雇用 令 (Employment of Natives Ordinance)」」は、雇用主に雇用人の住 宅保障を義務づけるものであり住宅供給政策の柱となるものであっ to

一方、最初の公営住宅が1935年に首都のルサカ市に建設された。 しかし、当時はアフリカ人労働力は農村からの出稼ぎ労働者であ り、都市の一時的居住者であるとみなされていたため、整備された 住宅充ずて男性単身労働者を想定したものであった。

1940年のアフリカ人鉱山労働者のストライキをきっかけにして、 1944年にエクレス委員会（Eccles commission）の「都市原住民居留 地における行政と財政に関する報告書」が提出され、これによって アプリカ人労働者の居住水準の改善が求められた。この勧告に基づ いて、1946年にアフリカ人住宅省が設立され、既婚アフリカ人の最 低居住水準注2) が定められた。

1948年には、住宅対策のための最初の立法である「アフリカ人都 市住宅令 (African Urban Housing Ordinance)」が制定され、地方 自治体にアフリカ人居住区の整销が求められた。これによって、自 治体は本格的に公営住宅の建設に乗り出すことになる。1956年には アフリカ人住宅委員会 (African Housing Board) を設立する新しい 住宅法を制定した。この間、公営住宅の建設も持続的に行われた が、都市人口の急速な増大に対して、住宅供給数は微々たるもので あった。例えば、1949年に 9,000 戸 $^{\text {あa9 }}$ のレンガ造住宅が建設された が、当時の都市部のアフリカ人叫141,000人にの弫っていた。

1950年代になると、スクウォッター (不法占拠) 居住区が拡大 成長していくが、これは都市部の周辺にできた建設労働者の飯場が 発端であった。1950年代中頃から、政府はアフリカ人の自助住宅建
設を奖励する目的で住宅補助金の減額・廃止を行ったが、この結 果、スクウォッターは急速に拡大していった。

表1 ザンビアの土地・住宅政策の推移

\begin{tabular}{|c|c|c|}
\hline & 年代 & 土地・住宅政策 \\
\hline \multirow{20}{*}{$\begin{array}{l}\text { 植 } \\
\text { 民 } \\
\text { 地 } \\
\text { 時 } \\
\text { 代 }\end{array}$} & 1900 & 北西部ローテシアで住宅税導入 \\
\hline & 1904 & 北東部ローデシアで住宅税道入 \\
\hline & 1917 & 鉱山健康保健規則：鉱山労的者に対する住宅供給の锤務つけ \\
\hline & 1927 & 地方自治令 \\
\hline & 1929 & 原住民雇用令 : 雇用人に対する住宅保障の翣務づけ \\
\hline & & 市町村命 \\
\hline & & 原住民登録令（～64）：労倠移钦の規制 \\
\hline & 1933 & 鉣山都市令 : 土地管理責任を政府に移行 \\
\hline & 1935 & アフリカ人向けの最初の公営住宅建設 \\
\hline & 1936 & 公有居住地に関する政策の䧹行：公共による宅地供給の推進 \\
\hline & 1939 & $\begin{array}{l}\text { 個人居住地令（〜 64）：行政機閣への登録、㕍用閶係にない個人の住 } \\
\text { 宅契約を認可 }\end{array}$ \\
\hline & 1940 & フォスター査問委員会の結成 : 労働者の住宅改良を進言 \\
\hline & 1944 & $\begin{array}{l}\text { エクレス委員会の報告「都市原住民居留地における、行政と財政に関 } \\
\text { する報告」 }\end{array}$ \\
\hline & 1946 & アフリカ人住宅省設立 \\
\hline & 1948 & 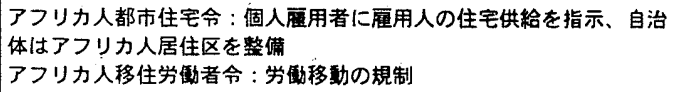 \\
\hline & 1950 代 & スクウォッター居住区の発生 \\
\hline & 1955 & 住宅補助金の削減（ 56) \\
\hline & 1956 & アフリカ人住宅委員会没立 \\
\hline & 1958 & 住宅補助金の廃止 \\
\hline & 1961 & 最初のアフリカ人向け計画住宅地区の建設 \\
\hline \multirow{20}{*}{$\begin{array}{l}\text { 共 } \\
\text { 和 } \\
\text { 制 } \\
\text { 時 } \\
\text { 代 }\end{array}$} & 1964 & 独立憲法による「移動と居住の自由権」の保滑 \\
\hline & & 原住民登録命と、個人居住地令の廃止 \\
\hline & 1965 & 内閣土地政策委員会の設置 \\
\hline & & $\begin{array}{l}\text { 移行開発計画：主要都市における公営住宅の建設、自治体に対する住 } \\
\text { 宅建設费補助、公務員住宅の建設、スクウォッター居住区の除去と住 } \\
\text { 宅水準の向上 } \\
\text { 回覧状17号: サイト・アント・サーピス区画整備を発表 }\end{array}$ \\
\hline & 1966 & 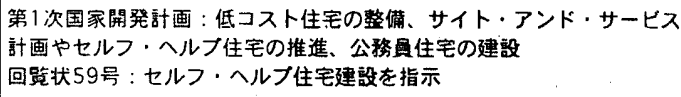 \\
\hline & 1967 & 内閣土地政策委負会の報告書：広範な土地間题を指摘 \\
\hline & & カウンダ大統領の「人道主埕」声明：土地問题に对する2つの提案 \\
\hline & 1968 & 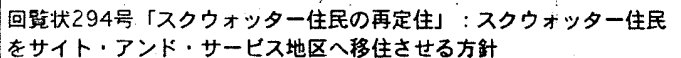 \\
\hline & 1970 & 土地取得法 : 土地収用をはかる \\
\hline & & 地主 ·借地人 (商業用途) 法 \\
\hline & 1971 & 国営住宅協会法 \\
\hline & & ザンビア改良地域法（改正） \\
\hline & 1972 & 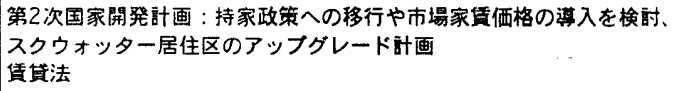 \\
\hline & 1973 & リーダーシップ規約 \\
\hline & 1973 & 建築協会法 \\
\hline & 1974 & $\begin{array}{l}\text { 法定改良地区住居法 : サイト・アンド・サーピスやアップグレードレ } \\
\text { たスクウォッターの定期借地梅を揌める } \\
\text { 土地測鲾法 }\end{array}$ \\
\hline & 1974 & 都市部画法 \\
\hline & 1975 & 土地法 \\
\hline & 1976 & 財産収用令 : 土地の国有化 \\
\hline & 1979 & $\begin{array}{l}\text { 第3次国家開発計画：最低居住水準の適用、持家政策の推進、低所得啳 } \\
\text { 住宅建設の偠先、公共住宅建設の優先 } \\
\text { 第4次国家開発計画：持家政策の推進 }\end{array}$ \\
\hline \multirow{5}{*}{$\begin{array}{l}\text { 民 } \\
\text { 主 } \\
\text { 化 } \\
\text { 時 } \\
\text { 代 }\end{array}$} & 1993 & 回管状13号：公務員住宅払い下げの珐可請求 \\
\hline & 1995 & 土地法：土地の売買を㴓め、土地市場を自由化した \\
\hline & 1996 & 住宅政策の発表：すべての収入䧄啳へのアフォータフルル住宅の供給を \\
\hline & & 自裳 \\
\hline & 1997 & 住宅プログラムを発表 \\
\hline
\end{tabular}


（2）共和制時代（1964年～1991年）

1964年に独立したザンビアは、独立憲法で「移動と居住の自由」 を定めた。この結果、農村から都市への人口移動が急速に增加し た。1963年から 1969 年の間の都市人口の年間增加率は $8.9 \%$ あ り、農村人口のそれは0.5\%であった。急速な都市人口の増加に対し て、自治体の住宅建設戸数は追いつかず、スクウォッター居住区は 拡大した。首都ルサカ市の人口は1972年に381,000人であり、これ に対して、当時のスクウォッター人口は、 60,000 人 150,000人とい われている。1970年に、ルサカ市の副都市計画官（Deputy Town Clerk）は、公営住宅のウエイティング・リストが、1965年以来 8,000世帯から21,000世帯に增えていることを示し、公共住宅の供給 不足を認めた。

独立後の最初の住宅政策は、「移行開発計画（Transitional Development Plan）（1965-1966）」 ${ }^{13)} に$ 見ることができる。この中 で政府は、主要都市に扔ける一般公営住宅の建設、自治体に対する 住宅建設費補助、公務員住宅の建設、スクウォッター居住区の除去 と住宅水準の向上を目標と定めた。公務員住宅の建設は、植民地時 代以来の雇用と住宅の夕イ・アップに基づく処置であり、近年に至 るまで住宅政策の優先課題として、遂行されてきている。

その後の住宅政策の推移注、第1次～第4次国家開発計画をみると 明らかである（表2） 14１5）16）17)。1965年から1971年にかけて、政府 は低コスト住宅の供給方法として、住宅の直接供給からサイト・ア ンド・サービス計画による宅地供給に重点を移行している。サイ ト・アンド・サービス計画は、住民の自助努力による住宅建設を前 提に、行政機関が行う宅地開発である。この計画によって1968年ま でに約5,000の区画が供給されたが、高い公共サービス料金の負担や 厳しい宅地取得の資格条件、自助住宅建設費の補助の不十分さなど に上り、成果は芳しくなかった。この計画に代わって、1973年から は、スクウォッター居住区のアップグレーディング計画が主流と なった。この計画は、スクウォッター居住区を撤去することなく、 道路や配水設借、上水道の整供を行って、居住環境の改善を行うも のである。スクウォッター居住区を、単に「無計画な」居住区とし て排斥するのではなく、社会的な財産として認識していく、という 方針がこの時期の国家開発計画で示されている。政府は、この計画 の推進にあたって、土地の収用を容易にするために、1974年に

「(法定改良地区) 住居法 (Housing (Statutory and Improvement Areas) Act）」を制定した。

一方、土地に関する政策の流れは、以下のようである。1965年、 政府は内閣土地政策委員会を設置し、1967年には土地に関する広範 な問題を内容とする報告書を作成して土地に関する立法の指針を示 した主4)。この報告書が出たあと、大統領は、土地の商品化の禁止な どの声明を発表している。さらに1970年に、土地収用をはかるため に「土地取得法（Lands Acquisition Act）」を制定した。ザンビア ではこの法律以前は、94\%が慣習による土地所有制度をとっていた が、この法律によって、政府は補償金と引き替えに強制的に土地を 収用できるようになった。またこれに先立って、1968年以降、政府 は主要な会社の株の51\%以上を保有し、企業の国営化を進めた。こ れらの企業は準国営企業（parastatal）と呼ばれている声5)。1975年に 「土地法（Land Act）」が制定されたが、1976年の「財産収用令」
の公布によっていっさいの土地が国有化淮6) され、土地法の多くは不 用となった。

ところで、第2次国家開発計画から打ち出されている持家化政策の 導入は、政府の財政力の問題や国際金融機関の介入に影響を受けて いる。政府は、家頎補助の削減や住宅の直接供給の削減によって、 藏出の縮小を図ろうとした。また、世界銀行やIMFなどの国際金融 機関は、構造調整を導入することで、経済の安定化を図ろうとし た。構造調整計画は、規制緩和、自由化、分権化、民営化・民活な どの改革措置からなり、発展途上国で深刻化していた過剩な政府規 制や、過大で非効率な政府機関の問題に対処するものである。しか し、このアプローチによって主食のとうもろこし粉の值上げが発表 されたのを契機に食糧暴動が発生し、1987年に構造調整政策は放棄 された。

1988年に、ルサカ市で、初めて一般公営住宅の払い下げが行われ $た^{18)}$ 。しかしこれは小規模なものであり、その後、公営住宅払い下 げ政策はほとんど進展しなかった。

（3）民主化の時代（1991年～現在）

新政権は、従来の社会主義理念を一掃し、国際金融機関との関係 の改善を図るため、再び構造調整政策に乗り出した。現在までに価

表2＼cjkstart国家開発計画に扮ける住宅政策とその成果

\begin{tabular}{|c|c|c|c|c|}
\hline & 第1次国家開発浢函 & 第2次国家開発㣌面 & 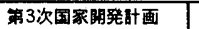 & 第4次国家開発豇画 \\
\hline 勍画期間 & $1966-1970$ & $1972-1976$ & $1979-1983$ & $1989-1993$ \\
\hline 目標 & 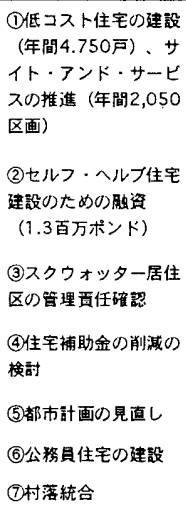 & 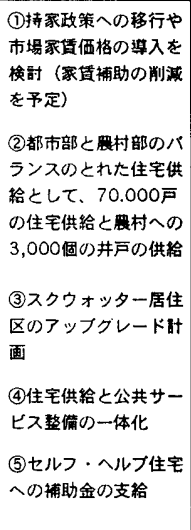 & 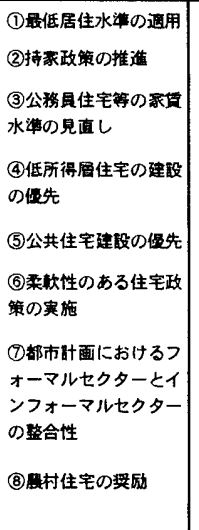 & 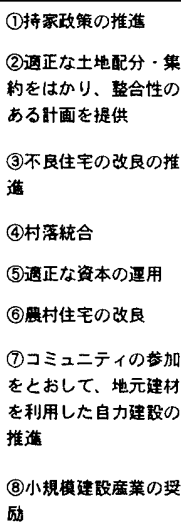 \\
\hline 成果 & 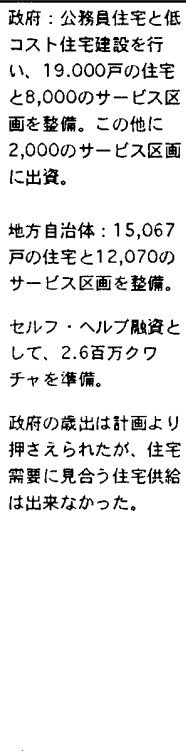 & 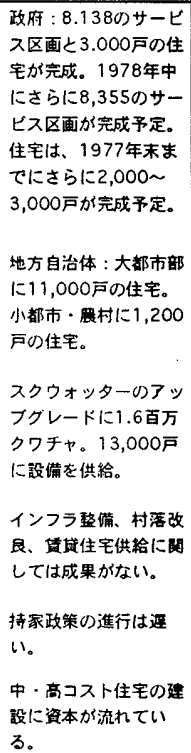 & 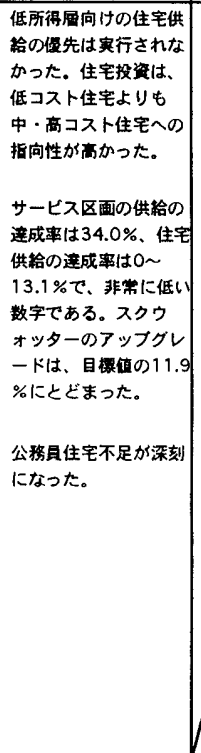 & \\
\hline
\end{tabular}


格の自由化、輸入規制緩和、為替の自由化、公企業への補助金削 減・撤廃、公企業の民営化などの施策に着手してきだ注7)。1997年11 月現在、民営化の対象となっている326の公社・国営企業のうち200 以上が民間に払い下げされたり契約を終えている(住)。最も重要な鍵 を握る銅鉱山会社（Zambia Consolidated Copper Mines）の払い下げ 先も1997年11月にすべて確定した。

1995年、新土地法功制定され、土地の売買が可能となり、土地市 場は自由化した。1996年1月に、政府は新しい住宅政策 ${ }^{19)}$ を発表し た。この住宅政策の目標は、すべての収入階層にアフォーダブル住 宅を供給することであるが、内容的には、新政府が推進しようとし ているイネーブリング・ストラテジー（Enabling Strategy）を踏襲 している。イネーブリング・ストラテジーとは、1986年にHabitatが 提唱した戦略である。この概念注、住宅供給に対する政府の直接的 な介入の除去を摧護しているが、住民支援よりも民活導入のための 規制緩和に傾いているという指摘がある ${ }^{20)}$ 。新しい住宅政策には、 持家化の推進が明記されており、その戦略として、家貨統制の廃止 や雇用主の雇用人に対する住宅供給の法的義務づけの廃止があげら れている。また、地方自治体の役割として、分讓または賃貸用の低 コスト住宅の建設があげられている。公営住宅の払い下げに関して はこの住宅政策には特に明記されていない。

政権交代後、公営住宅払以下げを含む持家政策の促進は新政府の 課題であった。公営住宅払い下げの主たる理由は、政府や自治体の 財政難による維持・管理能力の低下と、持家化による国民のエンパ ワーメント (empowerment：自助能力の強化) である。また、家貨 統制や補助金を削減して財政の縮小を図ったり、払い下げ益を新た な投資にあてる目的もあった。 1993年に、回覧状13号（Circular No.13 of 1993）で、公営住宅の払い下げの一環として公務員住宅の 払い下げに対する大臣への同意書が政府内で回覧されたが、これに 対する反応は鈍く、ほとんど何の進展もみられなかった。

公営住宅の払い下げが本格化するのは、1996年に大統領が公営住 宅払い下げの声明を出してからである。それは、1959年以前に建築 された老朽公営住宅は、登記料を払えば無料で居住者に払い下げら れるというものであった。これと前後して、政府は、1996年2月に 一般公営住宅払い下げのガイドラインを、9月に公務員住宅払い下げ のガイドライン2i)を、それぞれ示した。大統領の声明は、同年10月 の選挙を控えたものであったため、明らかに票榢ぎであったとする 意見も多い。選举後、1997年7月以来、公務員住宅の払い下げが一 時停止の状態になっていることはその一証左と言うこともできる。

\section{6. 公営住宅払い下げのガイドライン}

ザンビアの公営住宅は、Government Housingと呼ばれる中央政府 が供給主体のものと、Council Housing と呼ばれる地方自治体が供給 主体のものとの2種がある。前者は、主として公務員（行政事務職 等）を対象とした公務員住宅であり、一般に給与 ${ }^{( \pm 9)} の$ 䄪 $10 \%$ が家賃 として設定されている。後者は一般大衆を対象とした一般公営住宅 であるが、低所得層のみを対象としているわけではなく、住宅の夕 イプは低コスト・中コスト・高コストと各所得層に対応している。 フラット式の共同住宅もあるが、大半は2戸1か1戸建ての平屋であ る。住宅の広さは、1寝室〜 4 寝室である ${ }^{( \pm 10)}$ 。構造は、コンクリート
ブロック造モルタル塗り仕上げで、屋根は波形鉄板やアスベストシ 一トが多い。家筫は民間よりも安く設定されており、例えばンドラ 市では、2寝室タイプの一般公営住宅の家貨は、月額K9,000 (111) （1996年現在、1K[クワチヤ]=約0.1円）である。この他に企業住宅 として鉱山会社が供給していたものがあり、企業の民営化に伴っ て、これもまた民間に払い下げられている。

住宅のストック数は、1990年現在で表3、表4のようになっている 22) 25)。住宅紛数に対する公共住宅の割合は、中央政府と自治体をあ わせると約1割である。公共住宅の中には、病院や学校に付随する職 員住宅や兵舎なども含まれる。公務員住宅や一般公営住宅などの貿 貸住宅に限ると、公営住宅の割合は全体の約 3 分の1を占める。住宅 ストック数には、スクウォッター居住区などのインフォーマルな住 宅が相当数含まれている(12) ため、合法な住宅ストック数に占める公 営住宅の割合は、かなり高いと推測される。中央政府が持つ住宅ス トック、すなわち公務員住宅のうち、払い下げの対象となっている のは14,217戸（1997年現在）である。表の数字は1990年のものであ るので単純に比較は出来ないが、払い下げ住宅数は、中央政府が持 つ貢貸住宅ストック数 $(27,872$ 戸) の約半数以上にのはる。地方自 治体の払い下げ数は、各自治体の資料が揃わないため明確でない が、国内第3の大都市であるキトウェ市を例に挙价ると、払い下げ対 象住宅数は13,908戸（1997年現在）である。1990年のキトウェ市の 一般公営貨貸住宅ストック数は10,593戸望193. であるので、一般公営住 宅のほほ全部を民間に譲渡する予定であるといえそうである。

\begin{tabular}{|c|c|c|c|c|c|c|}
\hline 所有主体 & 全国 & (\%) & 都市 & (\%) & 䀁材 & $(\%)$ \\
\hline 中央政矿 (Central Govt.) & 63,463 & 4.8 & 42,923 & 8.8 & 20,540 & \\
\hline 地方自治凍(District Council) & 76,427 & 5.8 & 74,293 & 15.3 & 2,134 & 0 \\
\hline 準国学企業( & 84,388 & 6.4 & 76,332 & 15.7 & $8 ; 056$ & \\
\hline 尽間企檏等(Private Org.) & 22,328 & 1.7 & 11,491 & 2.4 & 10,837 & \\
\hline 㑑人( $(\mathrm{In}$ & $1,062,593$ & 80.4 & 276,163 & 56.7 & 786,430 & 94.2 \\
\hline 不朋 & 11,863 & 0.9 & 5,434 & 1.1 & 6,429 & \\
\hline$t$ & $1,321,062$ & 100.0 & 486,636 & 100.0 & 834,426 & 100.0 \\
\hline
\end{tabular}

\begin{tabular}{|c|c|c|c|c|c|c|}
\hline 形有主体 & 全国 & (\%) & 都直 & (\%) & 鹿杜 & (\%) \\
\hline 中央政椎(Central Govt.) & 27,872 & 11.5 & 20,145 & 9.5 & 7,727 & 25 \\
\hline 地方自治体(District Council) & 55,983 & 23.1 & 55,170 & 26.1 & 813 & 2. \\
\hline 㔼国営企策(Parastatal) & 50,461 & 20.8 & 47,812 & 22.6 & 2,649 & 8.7 \\
\hline 民間企亲等(Private Org.) & 6,485 & 2.7 & 4,542 & 2.1 & $, 1,943$ & 6. \\
\hline 個人(Individual) & 91,921 & 37.9 & 76,742 & 36.2 & 15,179 & 49.8 \\
\hline 不朋 & $9,564 !$ & 4 & 7,378 & 3.5 & 2,186 & 7.2 \\
\hline 壾 & $242,286:$ & 100.0 & 211,789 & 100.0 & 30,497 & 100. \\
\hline
\end{tabular}

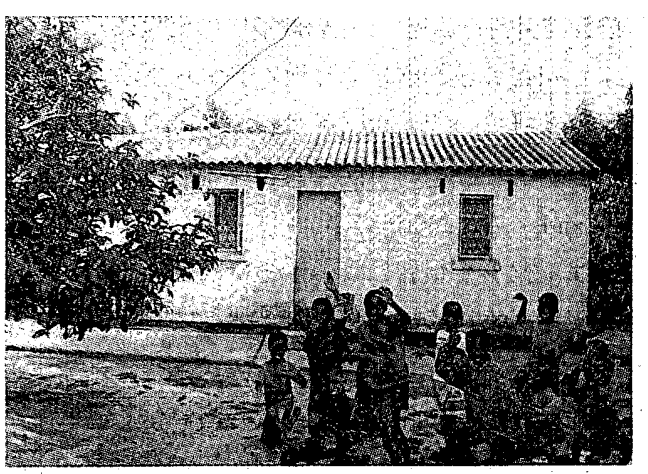

写真1 キトウェ市の公営住宅（カミトンド地区） 
公営住宅の払い下げは、その住宅の居住者のみを対象としてい る。住宅の払い下げ洒格は、公務員住宅と一般公営住宅で異なる。 住宅の払い下げ価格は、以下の3つの要素で決定される。

(1) 住宅の状態

住宅のメンテナンスの状態に関係なく、広さ（面積、室数）と 立地によって評価される。住宅のメンテナンスを問題にしないの は、維持管理の責任がある政府自身の㤐慢を居住者の資産価値に 影響させないためである。

(2) 居住者の勤続年数または居住年数

公務員住宅の場合は、住宅の評価額から、勤続年数 $\times 2 \%$ の割引 （最高40\%まで）が適用される。

一般公営住宅の場合は自治体によって対応が多少異なるが、一 般に居住年数 $\times 2 \%$ の割引が適用される。従って、50年以上、その 住宅に居住している場合は、割引率は100\%となる。大統領声明に よって1959年以前に建築された住宅が無料で払い下げられるとい うのは、このような割り引きシステムから発生している。さら に、一括払いで購入する場合には、20\%の割引が付加される。ま た、これまでの家賃の支払いが優秀な場合にも、割引率が加算さ れる(主16)。

（3）住宅市場

上記のような割引があるものの、基本価格は住宅市場で決定さ れる。民間住宅は、質が高く、価格も高いので、住宅市場で決定 される価格は、国民の収入と比較してかなり高額である。例え ば、ルサカ市の2寝室タイプの住宅の価格は、低コスト住宅地区で K3,500,000であり、中コスト住宅地区ではK8,000,000である。国 民の平均月収はK50,000 K100,000であるが、所得のほとんどは 食費に費やされて抢り、住宅費に拠出できる金額は非常に限られ ている゙๋17)。

以上のようにして決定された金額は、居住者が住宅購入の申請を

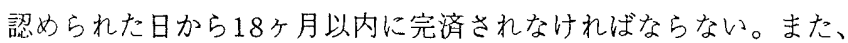
申請日から30４5日以内に、住宅価格の10\%を預託金として支払わ なければならない。

\section{7. 公営住宅払い下げの現況}

公務員住宅に関しては、現在、払い下げが停止されている。計画 中断の詳しい理由は不明だが、払い下げに伴う諸費用として、K30 億が必要であるといわれており、この拠出が困難であることが理由 の1つであると思われる。

自治体が供給主体の一般公営住宅の払い下げについては、キトウ エ市とンドラ市において、1996年と1997年にザンビア国立大学の学 生によってそれぞれ調査研究が行われており、その状況をみること ができる。

キトウェ市、ンドラ市の供給主体別住宅ストック数は、表5、表6

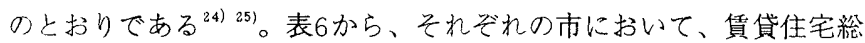
数に占める一般公営住宅の割合は、約半分に㧍よんでいることがわ かる。この割合は、全国における比率と比較すると、かなり高い (表4参照)。

(1) キトウエ市の場合

キトウエ市は、地方自治体の中でもいち早く一般公営住宅の払い
下げに着手した自治体である。1992年頃から一般公営住宅の払い下 げは推進されてきた。大統領の声明に従って払い下げ価格を設定し た現在のような形の払い下げシステムは、1996年3月から始まっ た。1997年現在の払い下げ対象住宅戸数は、13,908戸（うち、低． 中コスト住宅は13,790戸、高コスト住宅は118戸) である。住宅の払 い下げ戸数は表7のとおりである。また、払い下げの価格は表8のと おりである。払い下げられる住宅は老朽化したものが多く、最も新 しい住宅でも1972年の建築である ${ }^{26)}$ 。キトウェ市の場合、1959年以 前に建設された住宅は無料で、登記料等の事務費用としてK21,000が 必要である。それ以降の比較的新しい住宅は、住宅基本価格から居 住年数や家賃の納付状況に応じて割引を受ける。例えばチムウェム

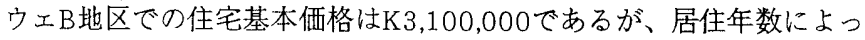
て最大 $80 \%$ の割引を受けることができ、さらに一括払いに伴う割引 やその他の割引が付加されるので、実際は平均K370,000で払い下げ られている。新旧住宅の価格差は大きく、新しい住宅は古い住宅の 17倍以上の額にのぼっている。現在の一般公営住宅の家賃幅は月額 K6,000 K15,000であるので、古い住宅は家質の3.5 月分、新しい 住宅恃約25ヶ月分以上にあたる。住宅価格の支払いは、K21,000の 登記手数料等のみで払い下げられる住宅については一括払い、それ

\begin{tabular}{l|r|r|r|r} 
表5 所有主体別住宅ストック数 (キトウエ・ンドラ) & \multicolumn{1}{c}{ (1990年) } & 主18) \\
\hline 所有主体 & キトウx市 & $(\%)$ & ンドラ市 & $(\%)$ \\
\hline 中央政府(Central Govt.) & 3,139 & 5.9 & 4,271 & 8.1 \\
地方自治体(District Council) & 11,507 & 21.8 & 13,974 & 26.3 \\
準国営企業(Parastatal) & 12,617 & 23.9 & 4,763 & 9 \\
民間企業等(Private Org.) & 1,963 & 3.7 & 1,393 & 2.6 \\
個人(Individual) & 22,661 & 42.9 & 27,969 & 52.7 \\
不明 & 924 & 1.8 & 675 & 1.3 \\
\hline \hline 計 & 52,811 & 100.0 & 53,045 & 100.0 \\
\hline
\end{tabular}

\begin{tabular}{|c|c|c|c|c|}
\hline 所有主体 & キトウェ市 & (\%) & ンドラ市 & $(\%)$ \\
\hline 中央政府(Central Govt.) & 957 & 4.2 & 1,401 & 6.2 \\
\hline 地方自治体(District Council) & 10,593 & 46.5 & 9,808 & 43.4 \\
\hline 準国営企業(Parastatal) & 5,171 & 22.7 & 2,373 & 10.5 \\
\hline 民間企業等(Private Org.) & 592 & 2.6 & 633 & 2.8 \\
\hline 個人(Individual) & 4,829 & 21.2 & 7,413 & 32.8 \\
\hline 不明 & 638 & 2.8 & 972 & 4.3 \\
\hline 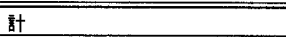 & 22,780 & 100.0 & 22,600 & 100.0 \\
\hline
\end{tabular}

\begin{tabular}{|c|c|c|c|c|c|}
\hline 地区 & 総戸数 (戸) & $\begin{array}{l}\text { 㓂却戸数（戸) } \\
\text { 1996年6月末 }\end{array}$ & $\%$ & $\begin{array}{l}\text { 完却戸数 (戸) } \\
\text { 1997年10月末 }\end{array}$ & $\%$ \\
\hline チムウェムウェA & 1,382 & 516 & 37.3 & 1,016 & 73.5 \\
\hline チムウェムウェB & 4,459 & 45 & 1 & 2,195 & 49.2 \\
\hline ンデケ & 2,898 & 13 & 0.4 & 1,849 & 63.8 \\
\hline カミトンド & 1,029 & 651 & 63.3 & 838 & 81.4 \\
\hline ブチ & 1,076 & 861 & 80 & 1,000 & 92.9 \\
\hline クワチャ & 2,066 & 662 & 32 & 1,699 & 82.2 \\
\hline クワチャ・イースト & $\begin{array}{r}880 \\
\end{array}$ & 17 & 1.9 & 496 & 56.4 \\
\hline 合部 & 13,790 & 2,765 & 20.1 & 9,093 & 65.9 \\
\hline
\end{tabular}

表8 一般公営住宅（低·中コスト）の払い下け価格 (キトウエ) ${ }^{\text {法21) }}$

\begin{tabular}{|c|c|c|c|c|}
\hline 地区 & 建築年 & $\begin{array}{l}\text { 住宅基本洒格 } \\
\text { (百万K) }\end{array}$ & $\begin{array}{c}\text { 㨸引率 } \\
(\%)\end{array}$ & $\begin{array}{c}\text { 登記料等 } \\
\text { (百万K） }\end{array}$ \\
\hline チムウェムウェA & & & 100 & 0.021 \\
\hline チムウェムウェ B & $1955-70$ & $3.10-4.60$ & $40-80$ & 0.021 \\
\hline ンデケ & $1955-72$ & $1.85-4.40$ & $40-80$ & 0.021 \\
\hline カミトンド & $1950-55$ & - & 100 & 0.021 \\
\hline ブチ & $1950-53$ & - & 100 & 0.021 \\
\hline クワチャ & $1955-59$ & - & 100 & 0.021 \\
\hline クワチャ・イースト & 1970 & $2.00-2.30$ & $40-80$ & 0.021 \\
\hline
\end{tabular}


以外の住宅は一括払いか分割払いを選択できる。分割払いの場合 岋、支払期間は18 月間である。表7から、払い下げ価格（登記手数 料等を除く)が無料の古い住宅と比べて、価格の高い新しい住宅の 払い下げは、1996年6月時点ではほとんど進んで扔らず、遅いペー スで展開していたことがわかる。1997年10月までの払い下げ戸数の 割合は、トータルで $65.9 \%$ ある。新しい住宅の払い下げ戸数の割 合は $55.1 \%$ であり、このうち $92.3 \%$ が分割払いによる購入であっ た。また、払い下げ価格が無料の住宅では、払い下げ数の割合は $82.0 \%$ である。K21,000の登記料が調達できないなどの理由から、約 $20 \%$ の居住者がまだ住宅を購入していない。

表9、表10は、1996年にキトウェ市内の公営住宅居住者を対象に して行った調查の結果を示したものである。公営住宅購入世帯、公 営住宅非購入世帯から、それぞれ35世帯を抽出して事例調查を行っ ている。公営住宅払い下げに関する住民調査は、ザンビア国内にも 事例がなく、貴重な資料である。サンブルが少ないため統計的検証 仗困難であるが、お抢よそ以下のようなことが指摘できる。まず、 表9から、一般公営住宅を購入した世帯とそうでない世帯の間には、 大点な収入格差があることがわかる。また、住宅を購入した人の資 金源は、個人の貯蓄や雇用主からの借り入れであり、金融機関の口 ーンの利用はない（表10）。

表9 一般公営住宅購入者と未購入者の収入 (キトウエ)

\begin{tabular}{|c|c|c|c|c|}
\hline $\begin{array}{l}\text { 收入幅 } \\
\text { (千クワチャ/月) }\end{array}$ & $\begin{array}{l}\text { 住宅を購入し } \\
\text { た世带 } \\
\end{array}$ & $\%$ & \begin{tabular}{|l|} 
住宅を購入し \\
なかった世带 \\
\end{tabular} & $\%$ \\
\hline 50未满 & 1 & 2.9 & 6 & 17.1 \\
\hline $50-99$ & 4 & 1.1 .4 & 21 & 60.0 \\
\hline $100-149$ & 4 & 11.4 & 3 & 8.6 \\
\hline $150-199$ & 1 & 2.9 & 0 & 0.0 \\
\hline $200-249$ & 3 & 8.6 & 0 & 0.0 \\
\hline $250-299$ & 1 & 2.9 & 0 & 0.0 \\
\hline 300以上 & 8 & 22.9 & 0 & 0.0 \\
\hline 不明 & 13 & 37.1 & 5 & 14.3 \\
\hline 計 & 35 & 100.0 & 35 & 100.0 \\
\hline
\end{tabular}

(出典) Moobela Cletus (1996) i‡22)

表10 一般公営住宅購入者の住宅購入資金源（キトゥェ）

\begin{tabular}{|c|c|c|}
\hline 資金源 & \begin{tabular}{|l} 
住宅を購入 \\
した世帝
\end{tabular} & $\%$ \\
\hline 個人の貯蓄 & 11 & 31.4 \\
\hline 雇用主からのローン & 3 & 8.6 \\
\hline 金融機関からのローン & 0 & 0.0 \\
\hline その他 & 8 & 22.9 \\
\hline 不明 & 13 & 37.1 \\
\hline 䧐市 & 35 & 100.0 \\
\hline
\end{tabular}

(出典) Moobela Cletus（1996）住23)

\section{(2〕ンドラ市の場合}

供給主体別住宅ストック数は、表5、表6のとおりである。1997年 現在では、18,869戸の一般公営住宅ストックがある。ンドラ市の公 営住宅も古いものが多く、1961年から1973年に建築されたものが大 半である。住宅の価格は、1954年以前に建築されたものが無料であ る。それ以降に建設された住宅の基本価格は、一般に、低コスト住 宅地区の1寝室2戸1タイプでK840,000、2寝室タイプでK1,400,000、 3垵室タイプでK2,100,000、4寝室タイプでK2,800,000となってい る。割引率は、1954年以前に建築された住宅が100\%、1960年代に 建築された住宅が40％、1970年代が30\%である。その他、条件に応
じて割引が付加される。中・高コスト住宅については異なる割引率 が適用されている。住宅価格の他に、登記料等の事務費用として K10,500が必要である(理)。

無料で払い下げられる住宅については、1996年の時点で約半数が 居住者に譲渡されている(ま25)。それ以外の住宅では、1,607戸が払い 下げされた。払い下げのペースは、キトウェ市よりも遅い。

表11、表12は、1997年にンドラ市内の公営住宅居住者を対象にし て行った事例調査の結果を示したものである。ンドラ市の一般公営 住宅の居住者の収入は表11のようになっている。調査対象の133世 帯のうち、住宅を購入した世帯が92世帯、手続き中の世帯が 10 世帯 あるので、キトウェ市の一般公営住宅居住者の調査結果よりも、収 入階層は上方に偏っている。K50,000〜 K100,000の所得階層にとっ ては、一般公営住宅の購入は難しいと推測される。住宅を購入した 世帯の資金源は、キトウェ市の場合と同様に㕍用主からの借り入れ や個人の貯蓄が多い。また、恩給や死亡見舞金などをあてている世 帯も多い。金融機関のローンは利用していない（表12）。

\begin{tabular}{l|r:r}
\multicolumn{3}{l}{ 表11 一般公営住宅居住者の収入 ンドラ } \\
\hline 収入幅 & 世帯数 & $\%$ \\
(チクワチャ/月) & $\%$ \\
\hline $50-100$ & 33 & 24.8 \\
$100-250$ & 64 & 48.1 \\
$250-400$ & 28 & 21.1 \\
400 以上 & 8 & 6.0 \\
\hline \hline 市 & 133 & 100.0 \\
\hline
\end{tabular}

(出典) Kampamba Johnson (1997) \$26)

\begin{tabular}{l|r:r}
\multicolumn{2}{l}{ 表12 一般公営住宅購入者の住宅購入資金源 (ンドラ) } \\
\hline 資金源 & 住宅を購入 & $\%$ \\
& した世带 & \\
\hline 個人の盯蓄 & 30 & 29.4 \\
雇用主からのローン & 30 & 29.4 \\
金融機関からのローン & 0 & 0.0 \\
事業の運用金 & 12 & 11.8 \\
親族や友人からの借金 & 8 & 7.8 \\
退職金、見舞金など & 22 & 21.6 \\
\hline \hline 計 & 92 & 100.0 \\
\hline
\end{tabular}

(出典) Kampamba Johnson (1997) ${ }^{(277)}$

\section{8. 住宅市場への影響と住宅取得者の動向}

公営住宅の払い下げに伴う問題を、払い下げシステムそのものが 抱える問題と、その波及効果として生じている問題の 2 点に分けるこ とができる。

(1) 公営住宅払い下げシステム自体の問題

(1) 住宅の老朽化による居住の安定性の不安

払い下げられる公営住宅の大半が老朽化の激しい住宅であり、 ライフスパンは2000年までと診断されている住28)。払い下げが進 んでも、4〜 5年内に建て替えや補修が必要である。所有権を譫渡 することによって、居住者の住宅の維持管理の向上は期待できる かもしれないが、住宅の構造強度そのものには限界がある。

(2) 価格や支払期限の設定等、払い下げシステムの欠陥 市場価格を導入して住宅本体に高い価格を設定し、その後、居 住者である低所得層保護のために大幅な割引を適用するというの が現在の価格決定システムである。しかし、安定した収入のない 
者や住居費を負担できないほどの低所得者には、大幅な割引洒格 もあまり意味を持たない。また、18ケ月という短期の支払期限 が、低所得層の負担になっており、現システムはむしろ、中・高 所得者を優遇したものとなっている。さらに、自治体にとって は、このような低価格販売は払い下げ益が出ないため財政補填に はつながらず、手続きや運営が大きな負担となっている。

(3) 払い下げ対象者の資格認定の欠陥

払い下げの対象者を居住者に限っているが、自治体の知らない 間に又貸しや居住者の入れ替わりが起こっている。払い下げの対 象として登録されている居住者が、実際は不在地主として又貸し 行為から利潤を得ている場合が多い（表13）。この場合、セカン ドハウスや投資目的で住宅を購入する者もあらわれている。ま た、新しい所有者によって、市場価格の新家質が導入されたり、 市場価格で転売されるという事態が生じている。市場価格での家 梖は、一般公営住宅家賃の3倍以上になることもある。表14による と、払い下げられた住宅の約3分の1が購入者によって 債貸しさ れて抢り、その8割以上がK30,000以上の家賃を設定している。こ れは、公営住宅家質の1.5〜 5倍に相当する。

\begin{tabular}{|c|c|c|}
\hline 住宅のタイブ & $\begin{array}{l}\text { 払い下げられ } \\
\text { た住宅 }\end{array}$ & $\begin{array}{l}\text { 払い下げられ } \\
\text { ていない住宅 }\end{array}$ \\
\hline $\begin{array}{l}\text { 又貸しされて } \\
\text { いる住宅 }\end{array}$ & 13 & 5 \\
\hline $\begin{array}{l}\text { 又貸しされて } \\
\text { いない住宅 } \\
\end{array}$ & 22 & 30 \\
\hline 計 & 35 & 35 \\
\hline
\end{tabular}

(出典) Moobela Cletus (1996) i玨29)

\begin{tabular}{l|r|r} 
表14 払い下げ住宅の新家貣（キトウェ） \\
\hline 家貨幅 & 払い下げられていない住宅 & \multicolumn{2}{|l}{$\begin{array}{l}\text { 払い下げられた住宅のうち, } \\
\end{array}$} & 又貸しされている住宅 \\
\hline K10,000以下 & 20 & 0 \\
K10,000-19,000 & 15 & 1 \\
K20,000-29,000 & 0 & 1 \\
K30,000以上 & 0 & 11 \\
\hline \hline 計 & 35 & 13 \\
\hline
\end{tabular}

(出典) Moobela Cletus (1996) 注30)

\section{(4) 融資制度の不㷍}

公営住宅の購入に際して18ケ月以内に完済するという条件があ るため、その費用の調達には、融資制度の活用が期待される。し かし、現状では、金融機関を利用している居住者はほとんどいな い。大半が、眝蓄や雇用主からの借金に頼っている。これは、金 融機関の低所得層に対する融資条件が厳しいためである。金融機 関の利子は年間 $50 \%$ から $60 \%$ に達し、融資条件として貯蓄残高な どの担保を課しているところもある。一方、雇用主からの借り入 れは、年利が比較的低ぐ氵31)、雇用を担保にしているため返済が容 易である。

(2) 公営住宅払い下げの社会的影響

(1) スクウォッ夕ーの拡大

住宅を購入した世帯の中には、市場価格で転売する者もあらわ れている。転売に対する規制はあるといわれているが、事実上、 無法状態である。例えば、キトウエ市のカミトンド地区の住宅は
K21,000の登記料だけで払い下げられたが、市場価格では K22,000,000の值段で転売されている。居住者は、この差益を生活 費にあててスクウォッターに移住する。住居よりもその日の生活 に苦慮する低所得層の現状がある。

また、住宅購入者が大家となって、店子に住宅を貨貸している 者が多く、キトウェ市でもそのような例が報告されている。この 場合、新家珼は公営住宅当時よりも一般に高く設定されており、 借家人の負担が増加している。このため、借家人の中には、スク ウォッターに移住を決める者があらわれてくる。

さらに、払い下げにより全体として公営住宅が減少しているた め、新規都市人口を含む低所得層の受け皿が減少している。加え て、政府の持家政策の奨励に伴い、新規の公営賃貸住宅の建設 は、第3次国家開発計画以来減少している。代わって、民間が賃貸 住宅の供給を行ってきたが、家顀が非常に高く設定されている。 このため、スクウォッターへの新規流入人口は増加していると推 測される。

\section{(2) 住宅市場の混乱}

公営住宅の払い下げは、既存の公営賃貸住宅ストックのほほ全部 を対象としているので、きわめて大量の低家賃住宅が貨貸市場から 姿を消し、低価格住宅として分讓市場で取引されることになる。例 えば、表5から、キトウェ市やンドラ市では、市内の全住宅ストッ クの約 5 分の 1 が市場を動く計算となるが、このようなドラステ イックな変化は、従来の住宅市場の需給均衡を大幅に変える要因と なりうる。事実、低家賃住宅が激減した賃貸住宅市場では、供給量 の過少により均衡家兵は高騰し、賃貸人の所得に見合わない高額な 家貨価格が設定されている。また、分謴住宅市場では低価格住宅の 增加による供給過剩で均衡価格は下落し、建設コストに見合わない 低額な住宅価格が設定されている。

\section{9. 結論}

ザンビアでは、「構造調整計画」のもとで、住宅政策も民営化を 意識するものに変化してきており、公営住宅の払い下げもその一環 として実施されてきた。しかし、民営化が社会の中で成熟していな い段階に扔けるこのような試みは、様々な混乱を招いている。

特に、低所得層に対する影響は大きい。老朽化した住宅の払い下 げは、低所得層の住宅状況を改善するものではない。また、支払期 間や価格の設定が低所得層よりもむしろ中・高所得層に有利に作用 していたり、住宅購入資金の融資制度が低所得層にとって厳しい条 件となっているため、現状では低所得層の払い下げ住宅の購入は困 難である。そのうえ、市場価格の導入や住宅市場の混乱によって低 所得層に対するアフォーダブル住宅が減少しており、低所得層には スクウォッターしか選択の道が残されていないような状況になって いる。一方政府は、公営住宅の払い下げを推進することで、持家化 による低所得層のエンパワーメントと、財政の安定化を試みたが、 現状ではいずれも失敗に終わっているといえる。

なお、本研究は、1998年度近畿支部研究発表会および1998年度日本建築学 会大会（九州）学術講演会において既発表である。研究に際し、ザンビア国立 コッパーベルト大学建設学部、キトウェ市役所、地方自治・住宅省のスタッフ の皆様にお世話になりましたことを記して謝意を表します。 
参考文献

1）、M.ポール・M.ハーロー・M.マーテンス著、大泉英次訳：住宅経済の構造 変動一欧米6力国の比較分析一、晃洋書房、1994

2）西垣昭・市村恭民：開発援助の経済学「共生の世界」と日本のODA、 有斐閣、 1993

3）森野勝好：西口清勝編著：発展途上国経济論、ミネルヴア曹房、1994

4）鈴木浩：80年代イギリスに扔ける住宅政策の展開、塩崎賢明・竹山清明 編著：賃貸住宅政策論、都市文化社、pp.265-279、1992

5）福島茂・大酉隆：マレーシアにおける民活型居住政策一国公有地の民営 化に上る低コスト住宅開発、都市計画論文集、第25号、pp.601.606、 1990

6）瀬戸口剛;：ロシア連邦政府における住宅政策の転換、都市住宅学、第19 号、pp.121·124、1997.9

7) Moobela Cletus: The Sale of Local Authority Houses and its Impact on Low Income Groups in Zambia: The Case of Kitwe, Thesis, The Copperbelt University, 1996 .

8) Kampamba Johnson: The Socio Economic Impact of the Sale of Council Houses: A Case of Ndola, Thesis, The Copperbelt University, 1997

9）小倉充夫：労㗢移動と社会変動一ザンビアの人々の営みから、有信堂高 文社、1995

10）データブックオブザワールド1996年版、二宮書店、1996

11），土屋哲・中村弘光：中原精一：アフリカの都市問題、明治大学社会科学 研究所叢書、勁草書房、1987

12) Simons HJ. et al. : Slums or Self-Reliance? Urban Growth in Zambia, University of Zambia, Institute for African Studies, 1976

13) Republic of Zambia : Transitional Development Plan 1965-1966, Government Printer, 1965

14) Republic of Zambia : First National Development Plan 1966 1970, Government Printer, 1966

15) Republic of Zambiá : Second National Development Plan 1972 1976, Government Printer, 1971

16) Republic of Zambia : Third National Development Plan 1979-1983, Government Printer, 1979

17) Republic of Zambia : New Economic Recovery Programme, Fourth National Development Plan 1989-1993, Government Printer, 1989

18) Mashamba M.S. : The Construction industry in Zambia: Opportunities and Constraints under the Structural Adjustment Programme and the Enabling Shelter Strategy, PhD Thesis, The University of Newcastle upon Tyne, 1997

19) Republic of Zambia : National Housing Policy, Ministry of Local Government and Housing, 1996

20）岩崎駿介・東村康文・芝原真紀：人間居住キーワード事典、中央法規、 1995

21) Republic of Zambia : Handbook on the Civil Service Home Ownership Scheme, Cabinet Office, 1996

22) Republic of Zambia : Census of Population, Housing and Agriculture 1990 Volume 10 Zambia Analytical Report, Central Státistical Óffice, 1995

23) Republic of Zambia ! Census of Population, Housing and Agriculture 1990 Descriptive TablesVolume 10 Zambia Total, Central Statistical Office, 1990

24) Republic of Zambia : Census of Population, Housing and Agriculture 1990 Volume 2 Copperbelt Province Analytical Report, Central Statistical Office, 1994

25) Republic of Zambia : Census of Population, Housing and Agriculture 1990 Descriptive Tables Volume 2 Copperbelt Province, Central Statistical Office, 1995

26) National Housing Authority : City of Kitwe Development Plan, Survey of Existing Condition, 1974

注

注1） "Housing Policy in Zambia” (Mashamba M.S., Copperbelt University, 1997)

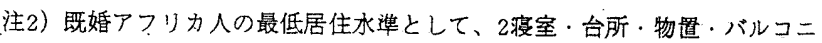
一と洗面所を設けた住宅を定めた。個々の住宅は、0.1エーカー以上の敖地 に十分なオーブンスペースをとった一戸建てとした。

注3）うち、2,500戸が公務員住宅であり、アフリカ人に対する貨貸住宅として 地方自治体に渡されたのは 6,500 戸である。

注4）しかし、この報告書が参考にした法制はすべてイギリスの不動産に関す

るものであり、ザンビア独自の法制は考えられていない。

注5）'parastatal'という語は、日本語では「公社」「第3セクター」等と訳 されることもある。

注6）すべての土地を政府との間に100年間の質借関係をつくる制度とした。

注7）国際協力事業团：<http://www.jica.go.jp/J-lib/Dp003.html >、 国別WID情報整備（ザンビア） 1995.3

注8） Zambia Privatisation Agency :

$<$ http://www.zamnet.2m/zamnet/zambus/2pa/ >

注9）公務員の給与は、官僚クラスで月額K200,000（1997年現在）。

Commission of Inquiryの調查 (salaries, salary structure and conditions of service in the public service in 1993）によると、ザンビア人の70\%以上が、 平均 5 人家族で、月積K 63,090 で生活している。

注10）第4次国家開発計画では、居住水华として、6人世带の居住面積を次の ように定めている。最低所得層 $12 \mathrm{~m}^{2}$ 、低所得層 $12 \sim 20 \mathrm{~m}^{2}$ 、低中所得層 $20 \sim$ $30 \mathrm{~m}^{2}$ 、中所得層 $30 \sim 45 \mathrm{~m}^{2}$ 、中高所得層 $45 \sim 60 \mathrm{~m}^{2}$ 、高所得層 $60 \mathrm{~m}^{2}$ 以上。

注1 1）民間住宅の家質は、低コスト住宅地区の2葠室タイブで、ルサカ市で月

額K150,000〜K200,000、ンドラ市で月額K50,000である。

注12）都市人口の約 $50 \%$ が主要都市部のスクウォッターに居住しているとい われている。

注13）表6で算出した数字なので、実数と注若干の謀差がある。

注14）参考文献22のTable11.12（p.170）および参考文献23のTable6.13 (p.279）加作成。

注15）参考文献22のTable11.13（p.172）および参考文献23のTable6.11 （pp.273.275）から作成。

注16）例えばンドラ市では、20年以上にわたって家質の支払いを禘りなく 行った居住者に対して、さらに20\%の割引を付加している。

注17) “Social Policy in the Context of Economic Reform - The Survival and Adaptive Strategies of Vulnerable Groups and their Policy Implecations Findings of the Base Line Survey on Zambia" - (Sapes Trust , 1997) の調査 によると、調査対象者の内、 $48.3 \%$ 月収K 100,000 以下である。1ヶ月の文 出の内、食費が占める割合が「全部」と答えたものが $40.9 \%$ 、「半分」と答 えたものが $47.7 \%$ ある。また、 $35.7 \%$ が1ヶ月の内で食事を渵足に食べれな い日があると回答している。

注18）参考文献24のTable11.12（p.138）と参考文献25の)Table6.13（pp.322 326）方作成。

注19）参考文献24のTable 11.13 （p.139）から作成。実数は割り屃しによって 算出したので、若干の誤差がある。

注20）キトウエ市役所のインタビューと参考文献7のTable4（p.68）から作 成。

注21）参考文䍊7のTable1（p.63）、Table4（p.68）から作成。参考文献26の Table 3.2 (p.41) 参照。

注22）参考文献7のTable5（p.69）。

注23）参考文献7のFigure9（p.76）加ら作成。

注24）1996年当時はK9,000であった。登記料等の事務費用は地方自治体に

よってその金類が異なる。

注25）参考文献7、p.68。実数などの詳細はわからない。

注26）参考文献8のFigure4.6（p.66）加作成。

注27）参考文献8のFigure4.3（p.57）施作成。

注28）参考文献7のTable 1（p.63）および参考文献26のTable3.2（p.41）を参 照。

注29）参考文献7のFigure10（p.78）加ら作成。

注30）参考文献70Table6（p.79）。

注31）参考文献8によると、㕍用主からの借り入れの年利は4 50\%で、中で も10\%以下という低利が多い。返済期間は1〜25年となっている。

(1998年 3 月13日原稿受理，1998年 9 月14日採用決定) 